\title{
How costly is particle therapy? Cost analysis of external beam radiotherapy with carbon-ions, protons and photons
}

Citation for published version (APA):

Peeters, A., Grutters, J. P. C., Pijls-Johannesma, M., Reimoser, S., De Ruysscher, D., Severens, J. L., Joore, M. A., \& Lambin, P. (2010). How costly is particle therapy? Cost analysis of external beam radiotherapy with carbon-ions, protons and photons. Radiotherapy and Oncology, 95(1), 45-53. https://doi.org/10.1016/j.radonc.2009.12.002

Document status and date:

Published: 01/04/2010

DOI:

10.1016/j.radonc.2009.12.002

Document Version:

Publisher's PDF, also known as Version of record

Document license:

Taverne

Please check the document version of this publication:

- A submitted manuscript is the version of the article upon submission and before peer-review. There can be important differences between the submitted version and the official published version of record.

People interested in the research are advised to contact the author for the final version of the publication, or visit the DOI to the publisher's website.

- The final author version and the galley proof are versions of the publication after peer review.

- The final published version features the final layout of the paper including the volume, issue and page numbers.

Link to publication

\footnotetext{
General rights rights.

- You may freely distribute the URL identifying the publication in the public portal. please follow below link for the End User Agreement:

www.umlib.nl/taverne-license

Take down policy

If you believe that this document breaches copyright please contact us at:

repository@maastrichtuniversity.nl

providing details and we will investigate your claim.
}

Copyright and moral rights for the publications made accessible in the public portal are retained by the authors and/or other copyright owners and it is a condition of accessing publications that users recognise and abide by the legal requirements associated with these

- Users may download and print one copy of any publication from the public portal for the purpose of private study or research.

- You may not further distribute the material or use it for any profit-making activity or commercial gain

If the publication is distributed under the terms of Article $25 \mathrm{fa}$ of the Dutch Copyright Act, indicated by the "Taverne" license above, 


\title{
How costly is particle therapy? Cost analysis of external beam radiotherapy with carbon-ions, protons and photons
}

\author{
Andrea Peeters ${ }^{\mathrm{a}, \mathrm{e}}$, Janneke P.C. Grutters ${ }^{\mathrm{a}, \mathrm{d}}$, Madelon Pijls-Johannesma ${ }^{\mathrm{a}, \mathrm{b}, *}$, Stefan $\operatorname{Reimoser}^{\mathrm{c}}$, \\ Dirk De Ruysscher $^{\mathrm{a}, \mathrm{b}}$, Johan L. Severens ${ }^{\mathrm{d}, \mathrm{e}}$, Manuela A. Joore ${ }^{\mathrm{d}, \mathrm{e}, 1}$, Philippe Lambin ${ }^{\mathrm{a}, \mathrm{b}, 1}$ \\ a Maastricht Radiation Oncology (MAASTRO Clinic), The Netherlands; ${ }^{\mathrm{b}}$ GROW Research Institute, University Medical Center, Maastricht, The Netherlands; \\ ${ }^{\mathrm{c}}$ Turner $\mathcal{E}$ Townsend, München, Germany; ${ }^{\mathrm{d}}$ Department of Health Organization, Policy E' Economics, Maastricht University, The Netherlands; \\ ${ }^{\mathrm{e}}$ Department of Clinical Epidemiology and Medical Technology Assessment, University Hospital Maastricht, The Netherlands
}

\section{A R T I C L E I N F O}

\section{Article history:}

Received 18 December 2008

Received in revised form 8 December 2009

Accepted 17 December 2009

Available online 26 January 2010

\section{Keywords:}

Particle therapy

Cost

Cost-effectiveness

Photon

C-ion

Hadron

\begin{abstract}
A B S T R A C T
Purpose: Particle therapy has potentially a better therapeutic ratio than photon therapy. However, investment costs are much higher. This study provides an estimation and comparison of the costs of these therapies.

Methods: Within an extensive analytical framework capital and operational costs, cost per fraction, and four tumor specific treatment costs are calculated for three facilities: combined carbon-ion/proton, proton-only, and photon.

Results: Capital costs for the combined, proton-only and photon facilities are: $€ 138.6$ million, $€ 94.9$ million, $€ 23.4$ million. Total costs per year are: $€ 36.7$ million, $€ 24.9$ million, $€ 9.6$ million. Cost per fraction is: $€ 1128$ ( $€$ 877-1974), $€ 743$ ( $€ 578-1300), € 233$ ( $€ 190-407)$. Cost ratio particle/photon therapy is 4.8 for the combined and 3.2 for the proton-only facility. Particle treatment costs vary from $€ 10,030$ (c-ion: lung cancer) to $€ 39,610$ (proton: head \& neck tumors). Cost difference between particle and photon therapies is relatively small for lung and prostate cancer, larger for skull-base chordoma and head \& neck tumors. Conclusion: Investment costs are highest for the combined carbon-ion/proton facility and lowest for the photon facility. Cost differences become smaller when total costs per year and specific treatment costs are compared. Lower fractionation schedule of particle therapy might further reduce its costs.
\end{abstract}

(C) 2009 Elsevier Ireland Ltd. All rights reserved. Radiotherapy and Oncology 95 (2010) 45-53
Particle therapy is a promising treatment modality for cancer [1], but it is also questioned whether it is "too expensive to become true" [2]. The investment costs are considerably higher than for the conventional photon therapy [3]. Treatment with charged particles, such as carbon-ions and protons, offers improved dose distributions to the target volume as compared to photon radiotherapy, with better sparing of the surrounding healthy tissues [4]. Potential gains of particle therapy might be (1) a higher tumor control probability due to dose escalation, (2) less side-effects including fewer secondary cancers due to less radiation to normal tissue. However, at the moment there is a controversial view on whether particle therapy is too expensive for the potential improvements in outcome claimed, or not [5]. This may be the main reason why a decision to adopt particle therapy as a standard treatment is pending in a number of countries. Cost-effectiveness analyses can give a decisive information on whether the extra costs are worth the extra effects [6]. An increasing number of studies report on the clinical effectiveness of particle therapy [7-10]. There is an ongoing

\footnotetext{
* Corresponding author. Address: Maastricht Radiation Oncology (MAASTRO Clinic), Dr. Tanslaan 12, 6229 ET Maastricht, The Netherlands.

E-mail address: madelon.pijls@maastro.nl (M. Pijls-Johannesma).

1 These authors contributed equally to this work.
}

debate on the cost issue as well [11,12]. The reported studies on cost-effectiveness of particle therapy differ substantially in terms of methodology and assumptions [13]. In order to determine whether the extra effects of particle therapy are worth the extra costs, an insight into the investment and operational costs of the facilities for particle therapies is crucial.

The present study specifies in detail the costs of radiotherapy and provides as such an input for future cost-effectiveness analyses. The aim was to determine the integral costs of external beam radiotherapy with carbon-ions, protons, and photons. The research objectives were to (1) develop an analytical framework for an integral cost calculation, (2) estimate the capital and operational costs of the facilities and the relative cost per fraction of carbon-ion and proton therapy as compared to photon therapy, (3) identify factors that influence the cost per fraction, and (4) calculate treatment costs for specific tumor sites.

\section{Methods}

\section{Framework for cost calculation}

To identify relevant cost items to be incorporated in the framework for the cost calculation the literature was searched for articles 
on costs and cost-effectiveness of particle therapy. The search revealed four relevant papers [3,14-16]. Through contacts with other researchers in the field additionally one report on hadrontherapy [17] and one extra cost article [18] were found. The cost results of these studies recalculated to the 2007 price level, using the consumer price index figures, are given in Table 1. Only one cost analysis was found, that compared particle therapy with intensitymodulated photon therapy [3]. This latter study includes detailed cost calculations with a large number of input parameters. Its format was used as a starting point for the development of the framework for the cost calculation in the present study.

\section{Calculation sheet}

The calculation sheet is developed in Excel $^{\mathrm{TM}}$. Costs can be calculated for three types of facilities: (1) combined carbon-ion and proton (further referred to as a combined facility), (2) proton-only, and (3) photon. The spreadsheet contains several sub-sheets with input parameters from which derived variables can be computed and from these finally the integral costs can be determined for each facility. The yearly throughput of patients is modelled in a detailed operational model. By adapting the input parameters a sensitivity of the calculated costs to any parameter change can be assessed.

\section{Breakdown of costs}

Costs are divided into two main categories: capital and operational costs. Capital costs consist of construction costs, costs of particle therapy equipment, and medical equipment costs (including linear accelerators - linacs for photon therapy, planning devices, computers, software etc.) Operational costs consist of costs for energy and utilities (water, heating, electricity); hard facility operating costs (maintenance of the: building, particle therapy equipment, medical equipment); soft facility operating costs (cleaning, insurance, administration, others); renewal costs (building, particle therapy equipment, medical equipment); and personnel (administration, clinical staff).

\section{Financial plan}

The whole-life costs for three different facilities are modelled and compared regardless of which sector is involved, private or public. An interest rate of $5 \%$ on the original initial funding, paid over 20 years, is included. This is added to the yearly operational costs. The lifetime of the facilities is expected to be 30 years plus. Within this period, parts of the facilities need to be replaced. It is modelled that all three facilities are being constantly renewed, including regular equipment replacement. For example, an annual renewal cost of $10 \%$ of the original funding for medical equipment allows, among others, a replacement of linacs in the photon facility every 10 years, which is the average estimated lifetime of a linac. For the renewal of particle therapy equipment a $2 \%$ and $1 \%$ annual rate is included for the combined facility and the proton facility, respectively (in addition to the $7 \%$ and $4 \%$ annual rate for regular maintenance).

\section{Sources of estimates}

The estimates for the input parameters are retrieved from different sources: literature, business plan Maastro Clinic [19], and a Belgian report on hadrontherapy [17]. Data on workflow, staffing, and personnel costs are customary to The Netherlands [20,21]. A detailed overview of the personnel costs can be viewed in Appendices 1 and 2. Costs are valued from a hospital perspective. Construction costs are based on previous projects by Turner \& Townsend, construction and management consultants. Costs for equipment are average benchmark prices as given by Turner \& Townsend for commercially available equipment.

\section{Basic assumptions}

The following assumptions are incorporated in the model: (a) There is a sufficient number of patients to make use of a maximum capacity of the facilities. (b) Cost per fraction is calculated for the following patient mix: (1) For particle therapy facilities - patients with special treatment category tumors, which are assumed

Table 1

Overview of the costs of particle therapy: outcomes of this study and costs found in the literature.

\begin{tabular}{|c|c|c|c|c|c|c|c|c|c|c|}
\hline \multirow[t]{2}{*}{ Study } & \multirow[t]{2}{*}{ Type of study } & \multirow{2}{*}{$\begin{array}{l}\text { Capital costs } \\
\text { Mean } \\
(\text { million } €)\end{array}$} & $\begin{array}{l}\text { Operational } \\
\text { costs/year }\end{array}$ & \multicolumn{3}{|c|}{ Cost per fraction } & \multicolumn{4}{|c|}{ Cost per treatment } \\
\hline & & & Mean (million $€$ ) & Beam & $\begin{array}{l}\text { Mean cost } \\
(€)\end{array}$ & $\begin{array}{l}\text { Range } \\
(€)\end{array}$ & Beam & $\begin{array}{l}\text { Mean cost } \\
(€)\end{array}$ & Range $(€)$ & Treatment description \\
\hline \multicolumn{11}{|l|}{ Combined facility } \\
\hline KCE report, [17] & Cost description & 159.6 & 17.5 & - & - & - & $\begin{array}{l}\text { C-ion or } \\
\text { proton }\end{array}$ & 24,700 & $\begin{array}{l}15,000- \\
40,000\end{array}$ & Average \\
\hline Jakel et al. [14] & $\begin{array}{l}\text { Cost-effectiveness } \\
\text { analysis }\end{array}$ & - & - & C-ion & 1030 & - & C-ion & 20,560 & - & $\begin{array}{l}\text { Skull-base chordoma; } \\
20 \text { fractions } \\
\text { (including planning) }\end{array}$ \\
\hline \multirow[t]{3}{*}{ Perrier et al. [18] } & Cost description & - & - & C-ion & 1130 & $\begin{array}{l}980- \\
1290\end{array}$ & C-ion & 22,590 & $\begin{array}{l}16,930- \\
28,240\end{array}$ & Average \\
\hline & & & & & & & & 22,100 & - & Prostate \\
\hline & & & & & & & & 14,800 & - & Lung (including planning) \\
\hline \multicolumn{11}{|l|}{ Proton-only facility } \\
\hline KCE report, [17] & Cost description & 75.2 & - & Proton & - & - & Proton & 19,100 & - & Average \\
\hline Konski et al. [15] & $\begin{array}{l}\text { Cost-effectiveness } \\
\text { analysis }\end{array}$ & - & - & Proton & - & - & Proton & 44,510 & $\begin{array}{l}30,380- \\
56,960\end{array}$ & Prostate \\
\hline $\begin{array}{l}\text { Lundkvist et al. } \\
\text { [16] }\end{array}$ & $\begin{array}{l}\text { Cost-effectiveness } \\
\text { analysis }\end{array}$ & 66.7 & - & Proton & - & - & Proton & - & $\begin{array}{l}10,790- \\
11,750\end{array}$ & $\begin{array}{l}\text { Medulloblastoma, Breast; } 25 \\
\text { fractions }\end{array}$ \\
\hline & & & & & & & & - & $\begin{array}{l}13,760- \\
14,280\end{array}$ & Prostate; 35 fractions \\
\hline \multirow{2}{*}{$\begin{array}{l}\text { Goitein and } \\
\text { Jermann, [3] }\end{array}$} & Cost analysis & 67.5 & 16.5 & Proton & 1110 & - & Proton & 27,660 & - & Average \\
\hline & & & & & & & & 15,880 & - & $\begin{array}{l}\text { Average (business costs } \\
\text { excluded) }\end{array}$ \\
\hline
\end{tabular}


eligible for particle therapy [20]. (2) For the photon therapy facility - a mix of standard and complicated cases as common in practice. (c) Treatment costs are calculated specific to each tumor, including the most sophisticated photon treatment. (d) Initial capital costs are evenly distributed/paid back over the assumed facility lifetime period. (e) Interest rate of $5 \%$ on the original initial funding is included. (f) The following costs are not included in the analysis: taxes (VAT), inflation and price changes over time, staff training, contingency, and demolishing works. (g) High standard service level for the hard and soft facility management services is assumed, resulting in a high technical availability of treatment rooms. (h) High treatment room utilization is based on: (1) A combined facility containing three treatment rooms, two of them equipped with either a proton gantry or a pair of fixed beams, third room equipped with a horizontal beam, a linac and synchrotron for acceleration, and a robotic patient positioning system. (2) A proton-only facility containing three treatment rooms, two of them equipped with a proton gantry, third room equipped with a horizontal beam, a cyclotron for particle acceleration, and a robotic patient positioning system. (3) A photon facility containing two treatment rooms equipped with standard linacs, in line with Goitein and Jermann [3]. (i) All facilities have equal image-guided equipment. (j) All reported costs are in euros (€), 2007 price level.

\section{Analyses}

\section{Base-case analysis}

Cost per fraction for each facility is calculated as total costs per year divided by the number of fractions per year. Total costs per year are a sum of the capital costs divided by the lifetime of the facility (30 years) and the yearly operational costs. Number of fractions per year is calculated in an operational model. In this model, first the maximum number of fractions per year per treatment room is calculated, as a ratio of the time available for treatment and the average time needed per fraction. This maximum number of fractions per room is then adjusted for the number of treatment rooms, the technical room availability, and the room utilization (limited by the accelerator availability; see Table 2). Capital costs for building, costs for maintenance, energy, water supply, cleaning, etc. depend on the gross floor area. This is explicitly calculated for all three facilities. To illustrate a number of patients expected to be treated per year in a facility, the total number of fractions per year is divided by the estimated average number of fractions per patient, specific for each facility (see Table 2). For a photon facility the estimation of the average number of fractions per patient is based among others on data from our clinic. For the particle facil-

Table 2

Base-case analysis: operational model and cost estimates.

\begin{tabular}{|c|c|c|c|c|}
\hline \multirow[t]{2}{*}{ Operation } & \multicolumn{2}{|l|}{ Particle facility } & \multirow{2}{*}{$\begin{array}{l}\text { Photon } \\
\text { facility }\end{array}$} & \multirow[t]{2}{*}{ Source } \\
\hline & Combined (carbon-ion and proton) & $\begin{array}{l}\text { Proton- } \\
\text { only }\end{array}$ & & \\
\hline Number of rooms & 3 rooms $^{\mathrm{a}}$ & 3 rooms $^{b}$ & 2 rooms $^{c}$ & Assumption \\
\hline Treatment category $^{\mathrm{d}}$ & Special & Special & Standard & Assumption \\
\hline Working days per week & 5 & 5 & 5 & Assumption \\
\hline Hours/day available for treatment & 14 & 14 & 14 & Assumption \\
\hline Days of operation/year & 250 & 250 & 250 & Assumption \\
\hline Time/fraction (average) & $18 \mathrm{~min}$ & $18 \mathrm{~min}$ & $10 \mathrm{~min}$ & Assumption \\
\hline Number of fractions/room & 11,667 & 11,667 & 21,000 & Outcome \\
\hline Treatment room utilization & $98 \%$ & $98 \%$ & $100 \%$ & Assumption \\
\hline Treatment room availability & $95 \%$ & $98 \%$ & $98 \%$ & Assumption \\
\hline Total number of fractions/year & 32,585 & 33,614 & 41,160 & Outcome \\
\hline Number of fractions/patient (average) & 18 & 20 & 18 & Maastro, data on file; Ref. [20]; Expert opinion \\
\hline Total number of patients/year & 1810 & 1681 & 2287 & Outcome \\
\hline \multicolumn{5}{|l|}{ Costs $(€)$} \\
\hline \multicolumn{5}{|l|}{ Capital costs } \\
\hline Medical equipment and IT & $13,750,000$ & $11,250,000$ & $14,250,000^{\mathrm{e}}$ & T\&T, data on file \\
\hline Particle therapy equipment & $90,000,000$ & $60,000,000$ & - & T\&T, data on file \\
\hline Building & $34,850,000$ & $23,680,000$ & $9,180,000$ & T\&T, data on file \\
\hline Total capital costs & $138,600,000$ & $94,930,000$ & $23,430,000$ & - \\
\hline Assumed lifecycle & 30 years & 30 years & 30 years & Assumption \\
\hline Capital costs/year & $4,620,000$ & $3,164,333$ & 781,000 & - \\
\hline \multicolumn{5}{|l|}{ Operational costs } \\
\hline Cost of operation/year & $10,952,350$ & $5,736,450$ & $2,758,350$ & T\&T, data on file \\
\hline Cost of renewal/year & $3,697,750$ & $2,080,200$ & $1,562,700$ & T\&T, data on file \\
\hline Cost of staff/year & $6,366,304$ & $6,366,304$ & $2,599,716$ & See Appendix \\
\hline Yearly interest for financing ( $5 \%$ over 20 years) & $11,121,623$ & $7,617,429$ & $1,880,084$ & Assumption \\
\hline Operational cost/year & $32,138,027$ & $21,800,383$ & $8,800,850$ & - \\
\hline Total costs/year & $36,758,027$ & $24,964,716$ & $9,581,850$ & - \\
\hline Cost/fraction & 1128 & 743 & 233 & - \\
\hline Ratio to photon & 4.8 & 3.2 & - & - \\
\hline
\end{tabular}

T\&T = Turner \& Townsend GmbH, construction and management consultants.

Maastro = Maastricht Radiation Oncology (Maastro Clinic), The Netherlands.

a 3 treatment rooms with 2 treatment rooms equipped with a gantry or a pair of fixed beams, third room equipped with a horizontal beam, a linear accelerator and synchrotron for acceleration, robotic patient positioning system.

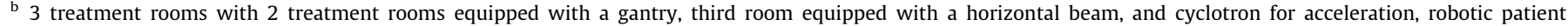
positioning system.

c 2 treatment rooms equipped with standard linear accelerators (in line with Goitein en Jermann [3]).

d Treatment categories for radiotherapy as given by Slotman and Leer [20].

e Including the cost of linear accelerators (linacs). 
ities the estimations are based on opinion of experts from particle facilities, backed up by evidence pointing out that the average number of fractions for carbon-ion treatment tends to be lower than the number of fractions for proton treatment, as shown in the trials.

\section{Sensitivity analyses}

The following items are varied to investigate their influence on the cost per fraction: (1) capital costs, (2) operational costs, (3) lifetime of the facilities, (4) patient throughput, (5) time per fraction, (6) treatment hours per day, (7) treatment room availability, (8) treatment room utilization, (9) energy costs, (10) interest rate, and (11) patient mix. With regard to the last: patients who require special treatments bring along higher costs due to a longer time per fraction and the use of sophisticated equipment. In The Netherlands teletherapy treatments are categorized into four groups, from T1 'simple' category (short radiation course) to T4 'special' category (e.g., 3D-conformal therapy with intensive megavoltage imaging and in vivo dosimetry, stereotactic radiotherapy, intensity-modulated radiotherapy - IMRT, and intra-operative radiotherapy) [20]. Slotman and Leer [20] calculated that for special category treatments (T4) the amount of resources is 2.9 times higher than for a standard treatment (T2 equivalent). In a sensitivity analysis this standard-to-special-treatment factor is varied between 1.5 and 5.

\section{Treatment scenarios}

To illustrate the actual treatment costs, these are calculated for four tumor indications: prostate, lung, head \& neck, and skull-base chordoma. In Table 4 the number of fractions and time to deliver a single fraction as used for the cost calculation for each tumor type are given. Treatment costs are calculated for a range of fractions based on actual clinical study protocols [22-51]. A linear relation between the number of fractions and the cost per fraction is assumed. No threshold value for fixed costs, e.g., for preparation of the treatment, is taken into account. Proton costs are calculated separately for a combined facility and a proton-only facility.

\section{Results}

\section{Base-case analysis}

A combined facility is most costly, with total costs per year of $€$ 36.7 million, followed by a proton-only facility with $€ 24.9$ million, and a photon facility with $€ 9.6$ million. Total yearly costs for the combined and proton-only facilities are 3.8 and 2.6 times higher as for the photon facility.

In the particle facilities approximately $87 \%$ of the annual costs are due to the operational and 13\% due to the capital costs. In the photon facility this is $92 \%$ and $8 \%$, respectively. Here not only the capital and operational costs are substantially lower, but also the total number of fractions per year is $18-21 \%$ higher. Cost per fraction is highest for the combined facility with $€ 1128$, followed by the proton-only facility with $€ 743$, and the photon facility with $€ 233$. Cost per fraction for the combined and proton-only facilities is 4.8 and 3.2 times higher as for the photon facility. The cost estimates are listed in Table 2.

\section{Sensitivity analyses}

A change in capital costs of $\pm 20 \%$ leads to a change in the cost per fraction of $\pm 2.5 \%$ for the particle and $\pm 1.7 \%$ for the photon facilities. A change in operational costs of $\pm 20 \%$ leads to a change in the cost per fraction of $\pm 17 \%$ for the particle and $\pm 18 \%$ for the photon facilities. This has only a small impact on the cost ratios. A shorter lifetime of a facility leads to a larger cost difference between particle and a photon facilities. $A \pm 20 \%$ change in the number of treated patients changes the cost per fraction with $-17 \%$ to $+25 \%$, assuming that the capital costs and operational costs have remained unchanged. When $30 \%$ less patients are treated the cost per fraction increases with $43 \%$. Halving of the number of patients doubles the costs. Shortening the time per fraction in the particle facilities with $4 \mathrm{~min}$ ( $14 \mathrm{~min}$ instead of $18 \mathrm{~min}$ ) causes a major reduction in the cost per fraction, notably in a combined facility. The cost ratios drop from 4.8 to 3.8 and from 3.2 to 2.5. Variation of the hours available for treatment, treatment room availability, and increased energy costs have a small impact on the cost ratios. When treatment room utilization for particle therapy is reduced from $98 \%$ to $90 \%$ the cost ratios increase to 5.3 and 3.5. Exclusion of the interest payment for financing reduces the cost per fraction with $30 \%$ for the particle and $20 \%$ for the photon facility. Cost per fraction for a photon facility increases from $€ 233$ to $€ 676$ when a value of 2.9 for the standard-to-special-treatment factor is applied [20]. The cost ratios decrease to 1.7 and 1.1 . The sensitivity analyses outcomes are presented in Table 3.

\section{Treatment scenarios}

Cost difference between particle and photon therapies is relatively small for the lung and prostate tumors, and larger for skull-base chordoma and head \& neck tumors. The lowest particle therapy costs are for inoperable stage I non-small cell lung cancer, namely $€ 10,030$ for treatment with c-ions and $€ 12,380$ for a proton treatment in a proton-only facility ( $€ 18,800$ in a combined facility). For this indication, the costs for photon treatment are $€$ 8150 for 3DRT and $€ 3720$ for SBRT. The highest particle therapy costs are for head \& neck tumors, $€ 30,080$ for a c-ion treatment, $€ 39,610$ for a proton treatment in a proton-only facility ( $€$ 60,160 in a combined facility). Costs for IMRT with photons for head $\&$ neck tumors are $€ 11,520$. In Figs. 1-4, the relation between the treatment costs and the number of fractions used is illustrated. Ranges around the average number of fractions, as given in Table 4, are used for these figures.

\section{Discussion}

In the presented study radiotherapy costs are determined for three different facilities: a combined carbon-ion and proton, a proton-only, and a photon facility. The best currently available information on most important factors contributing to and influencing the costs is incorporated. Construction costs, costs for running a facility, and throughput of patients are jointly used to calculate the cost per fraction for each facility. Additionally, specific treatment costs are determined for four cancer indications: prostate, lung, head \& neck, and skull-base chordoma. The calculated cost per fraction is: $€ 1128$ ( $€$ 877-1974) for a combined facility, $€$ 743 ( $€$ 578-1300) for a proton-only facility and $€ 233$ ( $€ 190-$ 407) for a photon facility. This gives a cost ratio to photon of 4.8 for a combined facility and 3.2 for a proton-only facility. Cost per fraction is sensitive to changes in operational costs and patient throughput. The tumor specific treatment costs for particle therapy range from $€ 10,030$ for lung cancer treatment with c-ions to $€$ 60,160 for head $\&$ neck tumors treatment with protons in a combined facility.

The calculated figures are inevitably associated with uncertainty. A high number of input variables is included, based on information from the literature, business data and expert opinion. The given cost ratios most likely approach reality better than the absolute costs. The above mentioned approach was chosen because 
Table 3

Sensitivity analyses: estimates of cost per fraction

\begin{tabular}{|c|c|c|c|c|c|}
\hline & \multicolumn{4}{|l|}{ Particle facility } & \multirow[t]{2}{*}{ Photon facility } \\
\hline & Combined carbon-ion and proton & Ratio to photon & Proton-only & Ratio to photon & \\
\hline \multicolumn{6}{|l|}{ Capital costs } \\
\hline Base case scenario & $€ 138,600,000$ & & $€ 94,930,000$ & & $€ 23,430,000$ \\
\hline Optimistic scenario (-20\%) & $€ 110,880,000$ & & $€ 75,944,000$ & & $€ 18,744,000$ \\
\hline Pessimistic scenario (+20\%) & $€ 166,320,000$ & & $€ 113,916,000$ & & $€ 28,116,000$ \\
\hline & Cost per fraction & & Cost per fraction & & Cost per fraction \\
\hline Base case scenario & $€ 1128$ & 4.8 & $€ 743$ & 3.2 & $€ 233$ \\
\hline Optimistic scenario $(-20 \%)$ & $€ 1100$ & 4.8 & $€ 724$ & 3.2 & $€ 229$ \\
\hline Pessimistic scenario (+20\%) & $€ 1156$ & 4.9 & $€ 762$ & 3.2 & $€ 237$ \\
\hline \multicolumn{6}{|l|}{ Operational costs } \\
\hline Base case scenario & $€ 32,138,027$ & & $€ 21,800,383$ & & $€ 8,800,850$ \\
\hline Optimistic scenario (-20\%) & $€ 25,710,421$ & & $€ 17,440,306$ & & $€ 7,040,680$ \\
\hline Pessimistic scenario (+20\%) & $€ 38,565,632$ & & $€ 26,160,459$ & & $€ 10,561,020$ \\
\hline & Cost per fraction & & Cost per fraction & & Cost per fraction \\
\hline Base case scenario & $€ 1128$ & 4.8 & $€ 743$ & 3.2 & $€ 233$ \\
\hline Optimistic scenario (-20\%) & $€ 931$ & 4.9 & $€ 613$ & 3.2 & $€ 190$ \\
\hline Pessimistic scenario (+20\%) & $€ 1325$ & 4.8 & $€ 872$ & 3.2 & $€ 276$ \\
\hline Lifecycle of a facility & Cost per fraction & & Cost per fraction & & Cost per fraction \\
\hline Base case: 30 years & $€ 1128$ & 4.8 & $€ 743$ & 3.2 & $€ 233$ \\
\hline 5 years & $€ 1837$ & 5.6 & $€ 1213$ & 3.7 & $€ 328$ \\
\hline 40 years & $€ 1093$ & 4.8 & $€ 719$ & 3.2 & $€ 228$ \\
\hline \multicolumn{6}{|l|}{ No. of patients per year ${ }^{\mathrm{a}}$} \\
\hline Base case scenario & 1810 & & 1681 & & 2287 \\
\hline Optimistic scenario (+20\%) & 2172 & & 2017 & & 2744 \\
\hline Pessimistic scenario $(-20 \%)$ & 1448 & & 1345 & & 1829 \\
\hline Pessimistic scenario $(-30 \%)$ & 1267 & & 1176 & & 1601 \\
\hline \multirow[t]{2}{*}{ Pessimistic scenario $(-50 \%)$} & 905 & & 840 & & 1143 \\
\hline & Cost per fraction & & Cost per fraction & & Cost per fraction \\
\hline Base case scenario & $€ 1128$ & 4.8 & $€ 743$ & 3.2 & $€ 233$ \\
\hline Optimistic scenario (+20\%) & $€ 940$ & 4.8 & $€ 619$ & 3.2 & $€ 194$ \\
\hline Pessimistic scenario $(-20 \%)$ & $€ 1410$ & 4.8 & $€ 928$ & 3.2 & $€ 291$ \\
\hline Pessimistic scenario $(-30 \%)$ & $€ 1612$ & 4.8 & $€ 1061$ & 3.2 & $€ 333$ \\
\hline Pessimistic scenario $(-50 \%)$ & $€ 2256$ & 4.8 & $€ 1485$ & 3.2 & $€ 466$ \\
\hline Average time per fraction (particle) & Cost per fraction & & Cost per fraction & & Cost per fraction \\
\hline Base case: $18 \mathrm{~min}$ & $€ 1128$ & 4.8 & $€ 743$ & 3.2 & - \\
\hline Optimistic scenario ( $-4 \mathrm{~min})$ & $€ 877$ & 3.8 & $€ 578$ & 2.5 & - \\
\hline Pessimistic scenario (+4 min) & $€ 1379$ & 5.9 & $€ 908$ & 3.9 & - \\
\hline Hours per day available & Cost per fraction & & Cost per fraction & & Cost per fraction \\
\hline Base case: 14 h/day & $€ 1128$ & 4.8 & $€ 743$ & 3.2 & $€ 233$ \\
\hline 8 h/day & $€ 1974$ & 4.8 & $€ 1300$ & 3.2 & $€ 407$ \\
\hline 16 h/day & $€ 987$ & 4.8 & $€ 650$ & 3.2 & $€ 204$ \\
\hline Treatment room availability & Cost per fraction & & Cost per fraction & & Cost per fraction \\
\hline Base case: 95\%, 98\%, 98\% & $€ 1128$ & 4.8 & $€ 743$ & 3.2 & $€ 233$ \\
\hline 90\% all facilities & $€ 1191$ & 4.7 & $€ 809$ & 3.2 & $€ 253$ \\
\hline Treatment room utilization (particle) & Cost per fraction & & Cost per fraction & & Cost per fraction \\
\hline Base case: $98 \%$ & $€ 1128$ & 4.8 & $€ 743$ & 3.2 & - \\
\hline $90 \%$ & $€ 1228$ & 5.3 & $€ 809$ & 3.5 & - \\
\hline Energy costs & Cost per fraction & & Cost per fraction & & Cost per fraction \\
\hline Base case: $100 € / \mathrm{MWh} / \mathrm{a}$ & $€ 1128$ & 4.8 & $€ 743$ & 3.2 & $€ 233$ \\
\hline $150 € / \mathrm{MWh} / \mathrm{a}$ & $€ 1147$ & 4.9 & $€ 749$ & 3.2 & $€ 236$ \\
\hline $200 € / \mathrm{MWh} / \mathrm{a}$ & $€ 1165$ & 4.9 & $€ 755$ & 3.2 & $€ 238$ \\
\hline Interest payment & Cost per fraction & & Cost per fraction & & Cost per fraction \\
\hline Base case: $5 \%$ over 20 years & $€ 1128$ & 4.8 & $€ 743$ & 3.2 & $€ 233$ \\
\hline $5 \%$ over 25 years & $€ 1089$ & 4.8 & $€ 716$ & 3.1 & $€ 228$ \\
\hline $5 \%$ over 30 years & $€ 1063$ & 4.7 & $€ 700$ & 3.1 & $€ 224$ \\
\hline No interest payment & $€ 787$ & 4.2 & $€ 516$ & 2.8 & $€ 187$ \\
\hline T4 category photon treatments only [20] & Cost per fraction & & Cost per fraction & & Cost per fraction \\
\hline Base case: standard treatment & $€ 1128$ & 4.8 & $€ 743$ & 3.2 & $€ 233$ \\
\hline Weight factor 1.5 & - & 3.2 & - & 2.1 & $€ 350$ \\
\hline Weight factor 2.9 & - & 1.7 & - & 1.1 & $€ 676$ \\
\hline Weight factor 5.0 & - & 1.0 & - & 0.6 & $€ 1165$ \\
\hline
\end{tabular}

${ }^{\text {a }}$ Assuming an average number of fractions per patient (specific for each facility).

at the moment there are no fully operational combined facilities in Europe that would allow an activity based costing, which would possibly give more accurate results [52]. The framework for calculation is however, set up in detail and extensive sensitivity analyses account for potential variations in the estimates.
The construction and operation of a radiotherapy facility depends on many local factors. The financial plan, budgetary conditions, construction/vendor market providing the facility and the equipment might differ internationally and even within one country. The presented model is a simplified reflection of a complex sit- 
Table 4

Number of fractions, time to deliver a single fraction, and corresponding treatment costs, as calculated by the model, for four different tumor indications.

\begin{tabular}{|c|c|c|c|c|c|}
\hline RT treatment per tumor indication & Number of fractions (average and range) & Time per fraction (min) & Source & Facility & Cost per treatment $(€)$ \\
\hline \multicolumn{6}{|l|}{ Prostate } \\
\hline C-ion & $20(16-26)$ & 10 & Ref. [22] & Combined & $\begin{array}{l}12,530(10,030- \\
16,290)\end{array}$ \\
\hline Proton & $39(34-44)$ & 10 & Refs. [23-25] & $\begin{array}{l}\text { Proton- } \\
\text { only } \\
\text { Combined }\end{array}$ & $\begin{array}{l}16,090(14,030- \\
18,160) \\
24,450(21,320- \\
27,590)\end{array}$ \\
\hline IMRT & $39(20-41)$ & 20 & Refs. [26-29] & Photon & $18,160(9310-19,090)$ \\
\hline 3DCRT & $36(20-40)$ & 10 & Refs. $[23,26,29,30]$ & Photon & $8380(4660-10,240)$ \\
\hline \multicolumn{6}{|l|}{ Lung $^{\mathrm{a}}$} \\
\hline C-ion & $4(1-18)$ & 40 (inclusive gating) & Ref. [31] & Combined & $10,030(2510-45,120)$ \\
\hline Proton & $10(10-20)$ & 30 (inclusive gating) & Refs. [32,33] & $\begin{array}{l}\text { Proton- } \\
\text { only } \\
\text { Combined }\end{array}$ & $\begin{array}{l}12,380(12,380- \\
24,760) \\
18,800(18,800-37,600)\end{array}$ \\
\hline SBRT & $4(1-10)$ & 40 & Ref. [34] & Photon & $3720(930-9310)$ \\
\hline 3DRT & $35(20-44)$ & 10 & Ref. [35] & Photon & $8150(4660-10,240)$ \\
\hline \multicolumn{6}{|l|}{ Head E' neck } \\
\hline C-ion & $16(16-24)$ & 30 & Ref. [36] & Combined & $30,080(30,080-45,120)$ \\
\hline Proton & $32(26-40)$ & 30 & Refs. [37-39] & $\begin{array}{l}\text { Proton- } \\
\text { only } \\
\text { Combined }\end{array}$ & $\begin{array}{l}39,610(32,180- \\
49,510) \\
60,160(48,880- \\
75,200)\end{array}$ \\
\hline IMRT & $33(25-35)$ & 15 & Refs. [40-45] & Photon & $11,520(8730-12,220)$ \\
\hline \multicolumn{6}{|l|}{ Skull-base chordoma } \\
\hline C-ion & $20(16-38)$ & 20 & Refs. [46,47] & Combined & $25,070(20,060-47,630)$ \\
\hline Proton & $37(25-42)$ & 20 & Refs. [48-50] & $\begin{array}{l}\text { Proton- } \\
\text { only } \\
\text { Combined }\end{array}$ & $\begin{array}{l}30,530(20,630- \\
34,660) \\
46,380(31,340- \\
52,640)\end{array}$ \\
\hline FSRT & $30(28-38)$ & 20 & Ref. [51] & Photon & $\begin{array}{l}13,970(13,040- \\
17,690)\end{array}$ \\
\hline
\end{tabular}

IMRT = intensity-modulated radiation therapy.

3DCRT $=$ three dimensional conformal radiation therapy.

SBRT $=$ stereotactic body radiation therapy.

3DRT $=$ three dimensional radiation therapy

FSRT $=$ fractionated stereotactic radiation therapy.

a Inoperable stage I non-small cell lung cancer.

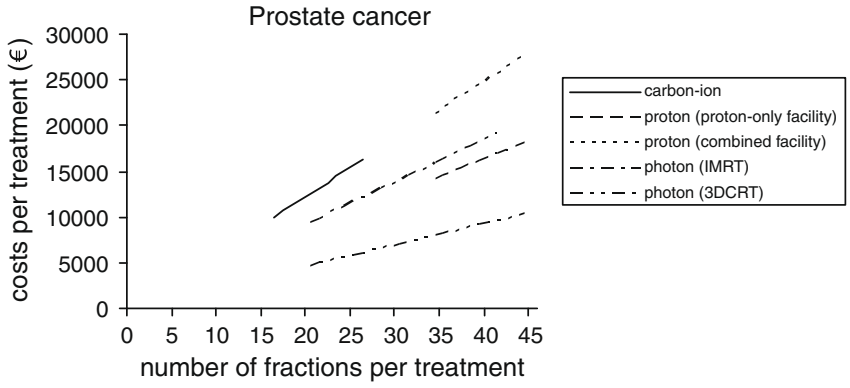

Fig. 1. Prostate cancer (A linear relation between the number of fractions and the cost per fraction is assumed. Although no threshold values for fixed costs, e.g., for preparation of the treatment, were taken into account in the model, for illustration, an expected minimal treatment cost of $€ 2500$ was used in the figures. IMRT = intensity modulated radiation therapy 3DCRT $=$ three dimensional conformal radiation therapy.

uation. Initial capital costs are evenly distributed over the assumed life cycle period of the facilities and an interest rate of $5 \%$ on the original funding is included. Both assumptions represent a conservative approach. Cost per fraction without interest payment is calculated to be $€ 787$, $€ 516$, and $€ 187$ for the combined, proton-only, and photon facility, respectively. This is about $70 \%$ of the base-case figures for the particle therapy and 80\% for the photon therapy.

The main input parameters are varied in the sensitivity analyses. Apart from the market developments and technical issues,

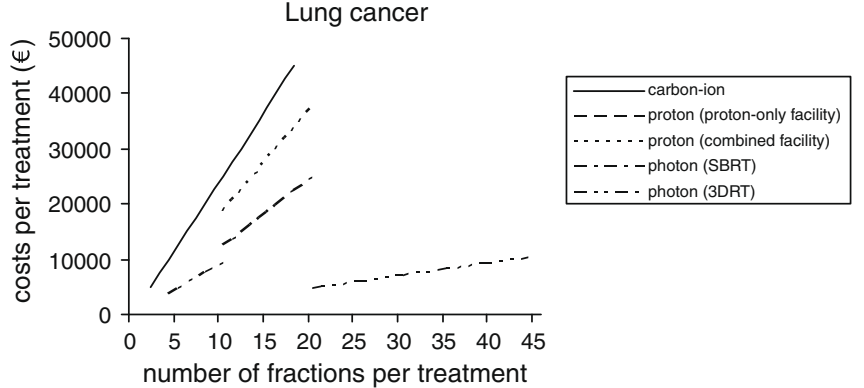

Fig. 2. Lung cancer (A linear relation between the number of fractions and the cost per fraction is assumed. Although no threshold values for fixed costs, e.g., for preparation of the treatment, were taken into account in the model, for illustration, an expected minimal treatment cost of $€ 2500$ was used in the figures. SBRT = stereotactic body radiation therapy. 3DRT $=$ three dimensional radiation therapy.

changes in a facility operation have an impact on the cost per fraction. There are at least two issues which influence the operational costs that are associated with running a new facility. First is the optimal use of a facility's capacity. In the present study a maximum capacity use is modelled. However, in practice it will presumably take some years before such a situation is reached. Cost per fraction will be higher before a facility is fully operational. Second issue is the learning effect. Costs of new health technologies tend to fall with time as the efficiency improves through experience. This has been showed in radiotherapy previously, for instance for 


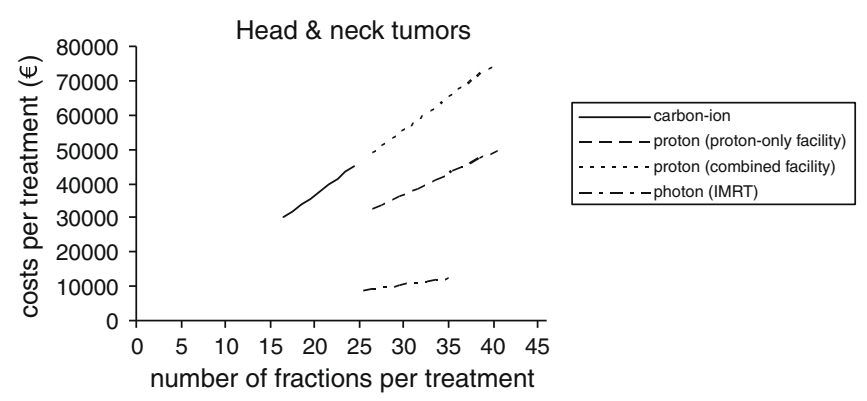

Fig. 3. Head \& neck tumors (A linear relation between the number of fractions and the cost per fraction is assumed. Although no threshold values for fixed costs, e.g., for preparation of the treatment, were taken into account in the model, for illustration, an expected minimal treatment cost of $€ 2500$ was used in the figures. IMRT = intensity modulated radiation therapy.

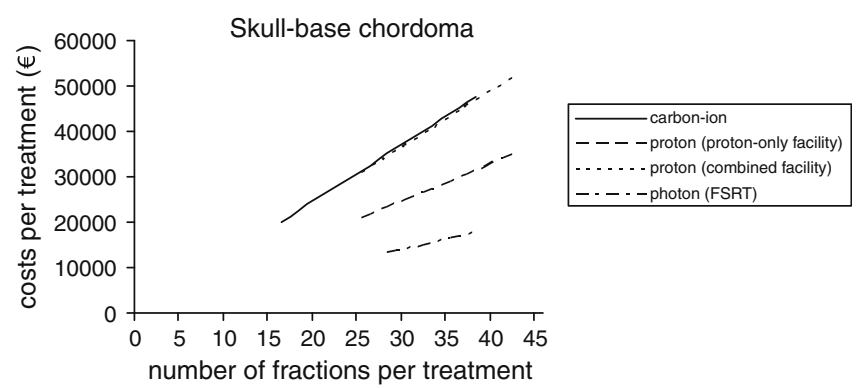

Fig. 4. Skull-base chordoma (A linear relation between the number of fractions and the cost per fraction is assumed. Although no threshold values for fixed costs, e.g. for preparation of the treatment, were taken into account in the model, for illustration, an expected minimal treatment cost of $€ 2500$ was used in the figures. FSRT $=$ fractionated stereotactic radiation therapy).

IMRT [53]. The above mentioned issues have an opposite effect on the costs. In the present study this is not explicitly modelled, but the operational costs have been varied, as has been the patient throughput.

Another issue to consider in a cost comparison of different facilities is the patient mix. The number of fractions delivered per year in a facility depends on the patient mix because this determines the average time per fraction. Complicated treatments often require more time per fraction than standard treatments. It can be assumed that once a facility is built, only patients are going to be treated who are qualified for treatment in such facility. For a photon facility this inevitably means a mix of standard and complicated cases. For a particle facility this will be mainly the complicated cases, at least at present. To demonstrate the average cost difference between the facilities, in the base-case analysis an average cost per fraction for each facility is calculated, assuming a mix of standard and complicated cases in a photon facility and complicated cases in a particle facility. For a comparison of the tumor specific treatment costs, the corresponding tumor specific treatment costs are calculated, including the most sophisticated photon treatment at present.

In the chosen three facility scenarios particle therapy is compared to photon therapy, consistent with the objective of this study. A rationale to combine c-ion and proton therapy in one combined facility is the technical advantage of using the same accelerator. A construction of an 'all inclusive' facility including treatment with c-ions, protons and photons is not included in this study. This might be of interest considering that some proton facilities (Boston, Loma Linda) use mixed beam treatment schedules, combining photon and proton radiation, e.g., for high risk prostate cancer patients $[24,25,54]$.
Regarding the specific treatment costs there are several points to discuss. Treatment scenarios for particle therapy are still in development. The fractionation schedules used in this study are based on the conducted trials. It is feasible that in the future treatments can be given with much fewer fractions than at present. This will reduce the treatment costs of particle therapy. Ultimately, the treatments' efficacy and toxicity will determine the cost-effectiveness of particle therapy as compared to photon therapy. However, in theory, any cost-effectiveness ratio will be more favourable for particle therapy in case fewer fractions per patients are used.

The actual impact of a reduced fractionation on costs, depends on how treatment costs are defined and valued. Number of fractions, time to deliver a single fraction, logistic aspects of treatment are all factors to which different weight might be attributed. Moreover, in practice different fixed cost thresholds are used. In the present paper the calculations are simplified, assuming linearity, without any threshold values for fixed costs. A tumor specific time per fraction is taken to calculate the cost per fraction, which is then multiplied by the number of fractions. This gives large treatment costs for tumors which require a large number of fractions and a long time to deliver a fraction at the same time. Therefore, treatment costs for head \& neck tumors, and the IMRT costs for prostate cancer are relatively high. Further, the calculated treatment costs roughly correspond with the costs found in the literature, as shown in Table 1.

The estimates of the cost per fraction correspond to the figures found in the literature (recalculated to the 2007 price level). For a combined particle facility no estimates could be found. Two studies reported a cost per fraction for a carbon-ion facility, $€ 1030$ [14] and $€ 1130$ [18]. These figures correspond to our estimate of $€$ 1128 . The cost per fraction of $€ 1110$ for proton therapy calculated by Goitein and Jermann [3] is higher than our estimate of $€ 743$, based on relatively high patient throughput in the particle facilities. In a recently published review on radiation costs, a maximum cost per fraction of photon therapy is $€ 190$ [55]. The cost calculated in this study is $€ 233$. The cost per fraction of photon IMRT was estimated by Goitein and Jermann [3] as $€ 460$. In our study the cost per photon fraction for special treatment category, such as IMRT, is $€ 676$.

This study is a first cost analysis that compares the costs per fraction and the costs per treatment for carbon-ion, proton and photon therapy. The estimated investment costs for a particle facility are much higher than for a photon facility, but this difference becomes smaller when the total yearly costs over the lifetime of the facilities are compared. Cost per fraction and also treatment specific costs are highly dependent on patient mix and throughput. The difference in treatment costs between particle and photon therapy is further reduced through the advantage of particle therapy to give treatments with fewer fractions. Ultimately, the clinical effectiveness of the treatments with charged particles will decide whether such treatments are cost-effective compared to photon therapy. Based on the results of this study, we can point out that depending on the indications selected for particle therapy, when a sufficient number of patients is available, and a facility is run efficiently, particle therapy may not be "too expensive to become true".

\section{Acknowledgements}

We would like to thank the following colleagues for their contribution to the paper: S.E. Combs (Heidelberg Ion Therapy Centre, Heidelberg, Germany), M. Engelsman (F.H. Burr Proton Therapy Center Massachusetts General Hospital, Boston, USA), G. Lammering (Maastro Clinic, Maastricht, The Netherlands), B.L.T. Ramaekers (Maastro Clinic, Maastricht, The Netherlands). 


\section{Appendix 1}

Table A1. Staffing plan for the facilities.

\begin{tabular}{llll}
\hline Staff & $\begin{array}{l}\text { Required } \\
\text { personnel } \\
\text { particle facility } \\
\text { (FTE) }\end{array}$ & $\begin{array}{l}\text { Required } \\
\text { personnel } \\
\text { photon facility } \\
\text { (FTE) }\end{array}$ & $\begin{array}{l}\text { Cost per } \\
\text { FTE }(€ / \\
\text { year) }\end{array}$ \\
\hline Director & 2 & 1.5 & 132,516 \\
$\begin{array}{l}\text { Physician } \\
\text { Financial }\end{array}$ & 8.2 & 4.2 & 132,516 \\
$\quad 1.4$ & 0.8 & 59,448 \\
manager & & 4.2 & 61,249 \\
$\begin{array}{l}\text { Research fellow } \\
\text { Bhysicist }\end{array}$ & 4.2 & 1.6 & 96,779 \\
Biologist & 1.5 & 0.1 & 96,779 \\
Technician & 15.7 & 1.5 & 51,174 \\
Radiation & 35.1 & 19.0 & 45,420 \\
$\quad$ technologist & 7.6 & 7.6 & 35,812 \\
Secretary & 91.3 & 40.4 & \\
Total & & & \\
\hline
\end{tabular}

FTE $=$ full time equivalent. Working hours per physician per week $=48$. Working hours per all other FTE per week $=36$. Productive hours/total working hours per FTE $=80 \%$.

Data based on Refs. [20,21] and Maastro Clinic, Maastricht, The Netherlands.

\section{Appendix 2}

Table A2. Total costs for staff for the facilities.

\begin{tabular}{lll}
\hline Costs for staff & $\begin{array}{l}\text { Particle } \\
\text { facility }(\mathrm{k} €)\end{array}$ & $\begin{array}{l}\text { Photon facility } \\
(\mathrm{k} €)\end{array}$ \\
\hline Cost for personnel & 6016 & 2428 \\
Cost for scientific committee & 50 & 50 \\
Contingency (5\%) & 301 & 121 \\
Total costs staff per year & 6366 & 2600 \\
\hline
\end{tabular}

\section{References}

[1] Schulz-Ertner D, Jakel O, Schlegel W. Radiation therapy with charged particles. Semin Radiat Oncol 2006;16:249-59.

[2] Lievens Y, Van den Bogaert W. Proton beam therapy: too expensive to become true? Radiother Oncol 2005;75:131-3.

[3] Goitein M, Jermann M. The relative costs of proton and X-ray radiation therapy. Clin Oncol (R Coll Radiol) 2003;15:S37-50.

[4] Schulz-Ertner D, Tsujii H. Particle radiation therapy using proton and heavier ion beams. J Clin Oncol 2007;25:953-64.

[5] Schulz RJ, Smith AR, Orton CG. Point/counterpoint. Proton therapy is too expensive for the minimal potential improvements in outcome claimed. Med Phys 2007;34:1135-8.

[6] Drummond M, Sculpher M, Torrance G, O'Brien B, Stoddart G. Methods for the economic evaluation of health care programmes. 3rd ed. Oxford: Oxford University Press; 2005.

[7] Brada M, Pijls-Johannesma M, De Ruysscher D. Proton therapy in clinical practice: current clinical evidence. J Clin Oncol 2007;25:965-70.

[8] Greco C, Wolden S. Current status of radiotherapy with proton and light ion beams. Cancer 2007:109:1227-38.

[9] Lodge M, Pijls-Johannesma M, Stirk L, Munro AJ, De Ruysscher D, Jefferson T. A systematic literature review of the clinical and cost-effectiveness of hadron therapy in cancer. Radiother Oncol 2007;83:110-22.

[10] Olsen DR, Bruland OS, Frykholm G, Norderhaug IN. Proton therapy - A systematic review of clinical effectiveness. Radiother Oncol 2007;83:123-32.

[11] Halperin EC. Overpriced technology in radiation oncology. Int J Radiat Oncol Biol Phys 2000;48:917-8.

[12] Zietman AL. The Titanic and the Iceberg: prostate proton therapy and health care economics. J Clin Oncol 2007;25:3565-6.

[13] Pijls-Johannesma M, Pommier P, Lievens Y. Cost-effectiveness of particle therapy: current evidence and future needs. Radiother Oncol 2008;89:127-34

[14] Jakel O, Land B, Combs SE, Schulz-Ertner D, Debus J. On the cost-effectiveness of carbon ion radiation therapy for skull base chordoma. Radiother Oncol 2007:83:133-8.

[15] Konski A, Speier W, Hanlon A, Beck JR, Pollack A. Is proton beam therapy cost effective in the treatment of adenocarcinoma of the prostate? J Clin Oncol 2007;25:3603-8.
[16] Lundkvist J, Ekman M, Ericsson SR, Jonsson B, Glimelius B. Proton therapy of cancer: potential clinical advantages and cost-effectiveness. Acta Oncol 2005;44:850-61.

[17] Huybrechts M, Obyn C, Gailly J, Mambourg F, Vinck I, Ramaekers D Hadrontherapy. Health Technology Assessment (HTA), Brussels: Federaal Keniscentrum voor de Gezondheidszorg (KCE). KCE reports 67A. 2007.

[18] Perrier L, Combs S, Auberger T, et al. A decision-making tool for a costly innovative technology: the case of carbon ion radiotherapy. J Econ Med 2007;25:367-80.

[19] Lambin P, Fekkers H, Daniels E, et al. Euregional ion therapy institute. Maastricht: Business Plan; 2005.

[20] Slotman BJ, Leer JW. Infrastructure of radiotherapy in The Netherlands: evaluation of prognoses and introduction of a new model for determining the needs. Radiother Oncol 2003;66:345-9.

[21] Oostenbrink JB, Bouwmans CAM, Koopmanschap MA, Rutten FFH. Manual for costing research. Amstelveen, The Netherlands: College voor zorgverzekeringen (Health Care Insurance Board); 2004.

[22] Tsujii H, Mizoe J, Kamada T, et al. Clinical results of carbon ion radiotherapy at NIRS. J Radiat Res (Tokyo) 2007;48:A1-A13.

[23] Nguyen PL, Zietman AL. High-dose external beam radiation for localized prostate cancer: current status and future challenges. Cancer J 2007;13: 295-301.

[24] Zietman AL, DeSilvio ML, Slater JD, et al. Comparison of conventional-dose vs high-dose conformal radiation therapy in clinically localized adenocarcinoma of the prostate: a randomized controlled trial. JAMA 2005;294:1233-9.

[25] Slater JD, Rossi Jr CJ, Yonemoto LT, et al. Proton therapy for prostate cancer: the Initial Loma Linda University experience. Int J Radiat Oncol Biol Phys 2004;59:348-52.

[26] Peeters ST, Heemsbergen WD, Koper PC, et al. Dose-response in radiotherapy for localized prostate cancer: results of the Dutch multicenter randomized phase III trial comparing $68 \mathrm{~Gy}$ of radiotherapy with $78 \mathrm{~Gy}$. J Clin Oncol 2006;24:1990-6.

[27] Zelefsky MJ, Fuks Z, Leibel SA. Intensity-modulated radiation therapy for prostate cancer. Semin Radiat Oncol 2002;12:229-37.

[28] Leibel SA, Fuks Z, Zelefsky MJ, et al. Intensity-modulated radiotherapy. Cancer J 2002;8:164-76.

[29] Leborgne F, Fowler J. Late outcomes following hypofractionated conformal radiotherapy vs. standard fractionation for localized prostate cancer: a nonrandomized contemporary comparison. Int J Radiat Oncol Biol Phys 2009;74:1441-6.

[30] Shipley WU, Thames HD, Sandler HM, et al. Radiation therapy for clinically localized prostate cancer: a multi-institutional pooled analysis. JAMA 1999;281:1598-604.

[31] Miyamoto T, Baba M, Sugane T, et al. Carbon ion radiotherapy for stage I nonsmall cell lung cancer using a regimen of four fractions during 1 week. J Thorac Oncol 2007;2:916-26.

[32] Bush DA, Slater JD, Shin BB, Cheek G, Miller DW, Slater JM. Hypofractionated proton beam radiotherapy for stage I lung cancer. Chest 2004;126: 1198-203.

[33] Hata M, Tokuuye K, Kagei K, et al. Hypofractionated high-dose proton beam therapy for stage I non-small-cell lung cancer: preliminary results of a phase $\mathrm{I} /$ II clinical study. Int J Radiat Oncol Biol Phys 2007;68:786-93.

[34] Lagerwaard FJ, Haasbeek CJ, Smit EF, Slotman BJ, Senan S. Outcomes of riskadapted fractionated stereotactic radiotherapy for stage I non-small-cell lung cancer. Int J Radiat Oncol Biol Phys 2008;70:685-92.

[35] Lagerwaard FJ, Senan S, van Meerbeeck JP, Graveland WJ. Has 3-D conformal radiotherapy (3D CRT) improved the local tumour control for stage I non-small cell lung cancer? Radiother Oncol 2002;63:151-7.

[36] Mizoe JE, Tsujii H, Kamada T, et al. Dose escalation study of carbon ion radiotherapy for locally advanced head-and-neck cancer. Int J Radiat Oncol Biol Phys 2004;60:358-64.

[37] Orecchia R, Zurlo A, Loasses A, et al. Particle beam therapy (hadrontherapy): basis for interest and clinical experience. Eur J Cancer 1998;34:459-68.

[38] Laramore GE. Role of particle radiotherapy in the management of head and neck cancer. Curr Opin Oncol 2009;21:224-31.

[39] Jereczek-Fossa BA, Krengli M, Orecchia R. Particle beam radiotherapy for head and neck tumors: radiobiological basis and clinical experience. Head Neck 2006;28:750-60.

[40] Rades D, Fehlauer F, Wroblesky J, Albers D, Schild SE, Schmidt R. Prognostic factors in head-and-neck cancer patients treated with surgery followed by intensity-modulated radiotherapy (IMRT), 3D-conformal radiotherapy, or conventional radiotherapy. Oral Oncol 2007;43:535-43.

[41] Kwong DL, Pow EH, Sham JS, et al. Intensity-modulated radiotherapy for earlystage nasopharyngeal carcinoma: a prospective study on disease control and preservation of salivary function. Cancer 2004;101:1584-93.

[42] Garden AS, Morrison WH, Wong PF, et al. Disease-control rates following intensity-modulated radiation therapy for small primary oropharyngeal carcinoma. Int J Radiat Oncol Biol Phys 2007;67:438-44.

[43] Chao KS, Majhail N, Huang CJ, et al. Intensity-modulated radiation therapy reduces late salivary toxicity without compromising tumor control in patients with oropharyngeal carcinoma: a comparison with conventional techniques. Radiother Oncol 2001;61:275-80.

[44] Kam MK, Teo PM, Chau RM, et al. Treatment of nasopharyngeal carcinoma with intensity-modulated radiotherapy: the Hong Kong experience. Int J Radiat Oncol Biol Phys 2004;60:1440-50. 
[45] Veldeman L, Madani I, Hulstaert F, De Meerleer G, Mareel M, De Neve W. Evidence behind use of intensity-modulated radiotherapy: a systematic review of comparative clinical studies. Lancet Oncol 2008;9:367-75.

[46] Protocol of National Institute of Radiological Sciences, Chiba, Japan (NIRS). $<$ http://www.nirs.go.jp/ENG/publications/pdf/radiological.pdf >

[47] Schulz-Ertner D, Karger CP, Feuerhake A, et al. Effectiveness of carbon ion radiotherapy in the treatment of skull-base chordomas. Int J Radiat Oncol Biol Phys 2007;68:449-57.

[48] Hug EB, Sweeney RA, Nurre PM, Holloway KC, Slater JD, Munzenrider JE. Proton radiotherapy in management of pediatric base of skull tumors. Int J Radiat Oncol Biol Phys 2002;52:1017-24.

[49] Munzenrider JE, Liebsch NJ. Proton therapy for tumors of the skull base. Strahlenther Onkol 1999;175:57-63.

[50] Noël G, Habrand JL, Jauffret E, et al. Radiation therapy for chordoma and chondrosarcoma of the skull base and the cervical spine. Prognostic factors and patterns of failure. Strahlenther Onkol 2003;179:241-8.
[51] Debus J, Schulz-Ertner D, Schad L, et al. Stereotactic fractionated radiotherapy for chordomas and chondrosarcomas of the skull base. Int J Radiat Oncol Biol Phys 2000;47:591-6.

[52] Player S. Activity-based analyses lead to better decision making. Health Care Financ Manage 1998;52:66-70.

[53] Bonastre J, Noel E, Chevalier J, et al. Implications of learning effects for hospital costs of new health technologies: the case of intensity modulated radiation therapy. Int J Technol Assess Health Care 2007;23:248-54.

[54] Gardner BG, Zietman AL, Shipley WU, Skowronski UE, McManus P. Late normal tissue sequelae in the second decade after high dose radiation therapy with combined photons and conformal protons for locally advanced prostate cancer. J Urol 2002;167:123-6.

[55] Ploquin NP, Dunscombe PB. The cost of radiation therapy. Radiother Oncol 2008;86:217-23 